\title{
Gingiva Metastasis of Renal Cell Carcinoma: A Rare Case Report
}

\section{Renal Hücreli Karsinomun Gingiva Metastazı: Nadir Bir Olgu Sunumu}

\author{
Erdem Öztürk ${ }^{1}$, İsmail Selvi ${ }^{1}$, Taha Numan Yıkılmaz ${ }^{1}$, Halil Çağrı Aybal $^{1}$, Ayşegül Erol$^{2}$, Halil Başar $^{1}$ \\ ${ }^{1}$ Dr. Abdurrahman Yurtaslan Ankara Onkoloji Eğitim ve Araştırma Hastanesi, Üroloji Kliniği, Ankara \\ ${ }^{2}$ Dr. Abdurrahman Yurtaslan Ankara Onkoloji Eğitim ve Araştırma Hastanesi, Patoloji Kliniği, Ankara
}

\section{ÖZET}

Renal hücreli karsinom, meme ve akciğer kanserlerinden sonra oral kaviteye metastaz yapan en sık üçüncü malignite olsa da, oldukça nadir görülmektedir. Gingivada metastaz yapması ise oransal olarak daha azdır ve bu tümörlerin ayırıcı tanıda akla gelmesi oldukça zordur. Genel olarak baş boyun bölgesine metastaz yapmış renal hücreli karsinomların prognozu oldukça kötü olup, bu aşamadan sonra beklenen sağ kalım 1 yıldan daha azdır. Tanıdan 1 ay sonra kosta metastazı gelişen renal hücre karsinomlu 51 yaşında bir erkek hastada, hedefe yönelik tedavilere rağmen, 42 . ayda oluşan gingiva metastazı olgusunu sunduk.

Anahtar Kelimeler: Çene kemiği osteonekrozu, gingiva, metastaz, oral kavite, renal hücreli karsinom

\begin{abstract}
Renal cell carcinoma is the third most common malignancy that metastasizes to the oral cavity after breast and lung cancers, but it is rarely seen. Metastasis to the gingiva is proportionally less and it is difficult for these tumors to come to mind in the differential diagnosis. Generally, the prognosis of renal cell carcinoma metastasizing to the head and neck region is quite poor and the expected survival is less than 1 year. We presented a 51-year-old male patient with renal cell carcinoma, developing costa metastasis 1 month after diagnosis and showing gingiva metastasis at 42 th months despite targeted treatment.

Keywords: Gingiva, jaw bone osteonecrosis, metastasis, oral cavity, renal cell carcinoma
\end{abstract}

\section{Giriş}

Renal hücreli karsinom (RHK), erişkin tümörlerin \%3'ünü oluşturmakta ve oldukça ölümcül seyretmektedir. Tanı anında olguların yaklaşık \%20-30'u metastatiktir. Yüksek vaskülarite özelliğinden dolayı, uzak anatomik lokalizasyonlara metastaz olma eğilimindedir. Metastazlar en çok akciğer, kemik ve lenf nodlarına olmaktadır.Baş boyun bölgesine metastaz yaygın değildir, olguların yaklaşık \% 6-18' inde görülür (1). Oral kavite metastazı ise çok daha nadirdir ve tüm oral kavite malign tümörlerinin ancak \%1'ini oluşturur. Oral kaviteye metastaz yapan en s1k infraklaviküler malignite erkeklerde akciğer, kadınlarda meme kanseridir. RHK ise en sık gözlenen üçüncü malignitedir. Maksillofasiyal bölgede, RHK metastazından en s1k etkilenen alan nazal kavite ve paranazal sinüslerdir ve bunları oral kavite izler. RHK öyküsü olan hastalarda, yeni gelişen oral kavite ve maksillofasiyal kitle varlığında, RHK metastazı akla gelmelidir.Metastatik RHK tanısı nedeniyle hedefe yönelik tedavi başlanmasına rağmen, progresyon gösteren ve 42 ay sonra gingiva metastazı yapan bir olgu sunduk.

\section{Olgu Sunumu}

Birkaç aydır var olan hematüri, istem dışı aşırı kilo kaybı (15 kg), halsizlik nedeniyle başvuran 51 yaşında erkek hastanın fizik muayenesinde her hangi bir patoloji saptanmadi. 20 paket/ y1l sigara kullanımı dışında özgeçmişinde bir özellik olmayan hastanın, biyokimyasal 
tetkiklerinde sadece malign hiperkalsemi (Kalsiyum: $13.4 \mathrm{mg} / \mathrm{dl}$ ) saptand1. Yapılan üriner ultrasonografide sol böbrek üst polde $12 \mathrm{~cm}$ çaplı şüpheli solid kitle saptanan hastanın abdomen tomografisinde (BT), sol böbrek üst polde $12 \times 8 \mathrm{~cm}$ boyutlu lobüle kontürlü, yer yer nekrotik alanlar içeren solid kitle izlendi. Kitle dalak, pankreas kuyruğu ve posteriordaki kas yapılarına invazyon göstermekteydi. Sol renal vende ve renal ven seviyesinde vena kava inferiorda tümör trombüsü, sol paraaortik alanda en büyüğü $2 \times 1.5 \mathrm{~cm}$ çaplı birkaç adet lenf nodu (LN) mevcuttu. Hospitalize edilen hastaya malign hiperkalsemi nedeni ile intravenöz hidrasyon ve zolendronik asit medikal tedavisi verildi. Sol böbrekteki kitlesine yönelik radikal nefrektomi önerilen hasta cerrahi müdahaleyi kabul etmedi. Bunun üzerine böbrekteki kitleye tru-cut biyopsi yapıldı ve patolojisi berrak hücreli RHK olarak yorumlandi. Medikal onkoloji tarafindan interferon alfa (IFN $\alpha$ ) tedavisi planland. IFN $\alpha$ tedavisini tolere edemeyen hastada, 1 ay sonra tüm vücut kemik sintigrafisinde (TVKS) sağ 10. kostada metastaz saptand 1 ve sorafenib+ zolendronik asit başlandi. 13. ayda her iki akciğerde birkaç adet $1 \mathrm{~cm}$ boyutlu metastatik nodüller gözlendi ve progresyon olması nedeniyle sorafenib kesilip everolimus başlandı. 32. ayda akciğer ve kemik metastazlarında progresyon olunca aksitinib başland1. 40. ayda zolendronik asit tedavisine bağlı çene kemiği osteonekrozu gelişince, zolendronik asit kesildi. Genel durumu bozulan, karında şişlik, kaşıntı, nefes darlığ 1 gelişen ve ağr1 yakınması artan hastanın kontrol BT' de karaciğerde büyüğü $8 \mathrm{~cm}$ çaplı multipl metastatik lezyonlar, sol surrenalde invazyon ve paraaortik LN boyutlarının $4 \mathrm{~cm}$ ' ye kadar büyüdügü izlendi. Hastaya nivolumab tedavisi planland1. 42. ayda ağız içinde mukozal kanama ve ağrı yakınması ile polikliniğimize başvuran hastanın yapılan muayenesinde sol mandibulada çene kemiği osteonekrozuna komşu alanda 1. molar diş hizasında gingivada $1 \mathrm{~cm}$ boyutlu polipoid kitle gözlendi. KulakBurun-Boğaz kliniğine danışılan hastanın, mevcut kitlesi eksize edildi. Mikroskopik incelemede; akantotik çok katlı yassı epitelyum ile örtülü kitlenin yüzeyinde ülserasyona yol açan şeffaf vakuoler sitoplazmalı, pleomorfik veziküler nükleuslu, belirgin atipik nükleoller içeren tümöral infiltrasyon izlendi ve tümör cerrahi sınır ile devamlılık göstermekteydi. İmmunhistokimyasal olarak; tümör hücrelerinin vimentin, CD10, EMA, RCC ile boyandı̆̆1; PAX8 ve CK7 ile boyanmadığı saptandı. Bu bulgularla berrak hücreli RHK infiltrasyonu olarak yorumlandı (Resim 1). Takiplerinde genel durumu giderek kötüleşen ve mevcut hali ile sistemik tedaviyi kaldıramayacak olan hasta, nefes darlığı, halsizlik, yaygın kemik ağrısı nedeniyle destek tedavisi amaçlı palyatif bakım ünitesine yatırıldı ve 44 . ayda hasta kaybedildi.

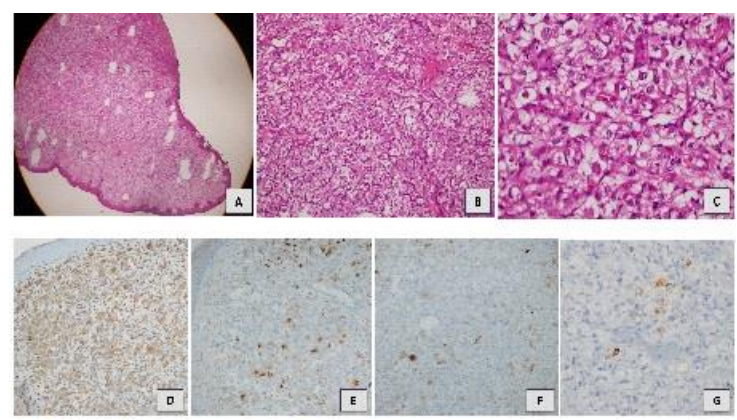

Resim 1: Gingivaya ait mukozal doku örneğinde, çok katlı yassı epitelde ülserasyona neden olan, büyük bir kısmı şeffaf vakuole sitoplazmal, pleomorfik, veziküler nükluslu, nükleolleri belirgin, diffüz atipik hücre infiltrasyonu izlenmektedir(A,B,C). İmmünhistokimyasal olarak Vimentin ile yaygin (D), CD10 (E) ve EMA (F) ve RCC (G) ile fokal boyanma izlenmektedir.

\section{Tartışma}

RHK tüm erişkin kanserlerin yaklaşı \% 3' ünü, primer böbrek malignitelerinin ise \% 90-95' ini oluşturur. Olguların \% 25-30' u tanı anında metastatiktir. En s1k metastaz yaptı̆̆ yerler; akciğer (\% 33-72), intraabdominal LN (\% 3-35) ve kemiktir (\% 21-25) (2). Baş boyun bölgesine $\% 15$ oranında metastaz yapmakta olup çoğu hematojen yolla olmaktadır (3). İntraabdominal ve intratorasik basınçta artış olduğunda, buradaki venöz sistemden prevertebral ve vertebral venöz pleksusa (Batson venöz 
pleksusu) geri akım oluşmakta, bu sayede tümör hücreleri pulmoner kapiller filtrasyonu atlayarak, baş boyun bölgesine metastaz yapabilmektedir(4). Özellikle berrak hücreli RHK' un primer tümör rezeksiyonundan yıllar sonra bile, bu hematolojik yay1lım yolunu kullanarak alışılmışın dişında anatomik bölgelere metastaz yaptığı gözlenmiştir.

Baş boyun bölgesine metastazlar en s1k paranazal sinüslere olurken, bunu oral kavite takip eder. Daha az oranlarda ise burun, larinks, temporal kemik ve tiroid bezinde gözlenmektedir. Oral kavite içerisinde metastazlar en s1k gingiva ve alveoler mukozada (\% 54.8) olmakta, ikinci s1kl1kta ise dilde (\% 27.4) görülmektedir(5). Gingival inflamasyon varlığı, metastatik hücrelerin oral mukozaya yerleşmesini kolaylaştı̆̆ından, bu hastalarda oral hijyen önem taşımaktadır. Bizim olgumuzda da, zolendronik asit tedavisine bağl1 olarak hastamızda gelişen çene kemiği osteonekrozu, bu duruma katkı sağlamıştır.

Oral kavitedeki metastatik tümörler, tüm oral kavite malign tümörlerinin \%1'ini oluşturduğundan, tanısal zorluklara neden olmaktadır. En sık meme, akciğer ve böbrekten kaynaklanırlar. Bu metastatik lezyonlar, biçim olarak basit ağrısız bir fibromayı, lokalize hiperplazik bir mukozal lezyonu taklit edebileceği gibi; hassas, kanama eğilimi gösteren damarsal benign bir lezyon olan pyojenik granülom şeklinde de ortaya çıkabilir. Özellikle öncesinde bilinen primer bir tümör öyküsü olmayan olgularda, başvuru semptomu oral kavitede kitle veya atipik mukozal lezyon olduğunda, ayırıcı tanıya gitmek oldukça zordur. Nitekim,Yoshitomi ve ark. başvuru semptomu olarak pyojenik granülomu taklit eden bir lingual kitle ile gelen hastaya, başlangıçta yanlış tanı koyup sonradan bunun RHK'a ait lingual metastaz olduğunu anladı (6).

İlk kez 1980' de Buchner ve ark. gingival yerleşimli hiperplastik bir lezyonu taklit eden metastatik RHK olgusu sundu(7). Oral kavite içerisinde, gingiva (8) ve dil(9) dışında diğer metastaz görülen yerler; bukkal mukoza, mandibula, orofarinks, tükürük bezleri (10) olarak bildirilmiştir. Majewska ve ark. tükürük bezlerini tutan berrak hücreli RHK metastazını içeren 9 olguluk seride; 7 olgunun parotis bezini, 1 olgunun submandibular bezi, 1 olgunun ise oral kavitedeki minor tükürük bezini tuttuğunu bildirdi (10) Oral kavite metastazlarında ilk belirtiler ağrı, şişlik, diş mobilitesi, kanama, çene ekleminde spasm, trismus iken; kitlenin büyümesine ve lokalizasyonuna bağlı ileri dönemlerde konuşma, yutma, çiğneme güçlüğü, ağız içerisinde tükürük birikmesi gibi bulgular gözlenebilmektedir.

Bolat ve ark. metastatik RHK tanılı hastalarında, IFN $\alpha$ tedavisi altındayken, literatürde ilk kez tedaviye rağmen,gingiva metastazı geliştiğini belirttiler(11). Bizim olgumuzda ise 42 aylık sürede kullanılan IFN $\alpha$, sorafenib, everolimus, aksitinib tedavilerine rağmen sürekli progresyon gelişmiş ve en sonunda nivolumab tedavisi başlanması planlanmışken gingiva metastazı oluşmuştur. $\mathrm{Bu}$ durum bize, hedefe yönelik tedavilerin ileride gelişebilecek bir gingiva metastazına engel olmadığını göstermektedir.

Primeri bilinmeyen oral kavite metaztazlı olgularda, immunhistokimyasal belirteçlerin tanısal değeri büyüktür. Özellikle metastatik berrak hücreli RHK ayırıcı tanısında; tükürük bezlerinin berrak hücreli karsinomları, odontojenik berrak hücreli karsinomlar, berrak hücreli myoepitelyal tümörler tanısal zorluğa neden olmaktadır. Berrak hücreli RHK, karakteristik olarak CD10, PAX8, RCC belirteçleri ile pozitif boyanmaktadır. Yine diğer metastatik tümörlerden farklı olarak, RHK olgularında sitokeratin ve vimentin pozitifliği mevcuttur. Bizim olgumuzda gingival yerleşimli kitle PAX8 ile boyanma göstermese de, hastanın bilinen RHK tanısının olması ve tümöral kitlenin vimentin, CD10 ve RCC ile boyanması, RHK metastazını destekleyen bulgulardır. 
Her ne kadar Kyan ve Kato, lingual metastazlı bir RHK olgusunda, eksizyonu takiben INF $\alpha$ ve interlökin 2 (IL2) tedavisi ile 2 y1llık rekürrenssiz sağ kalım elde etmiş olsalar da (12); baş boyun bölgesine metastatik RHK olgularında prognoz oldukça kötüdür ve metastaz saptandıktan sonra sağ kalım süresi ortalama 6-9 aydır. Bizim olgumuzda da gingivada metastaz saptandiktan 2 ay sonra genel durumu kötüleşen hasta kaybedildi.

Oral kavite metastazlarında tedavide lokal eksizyon önerilmektedir. Burada primer amaç, metastatik kitlenin neden olacağı ağr1, kanama, enfeksiyon gibi komplikasyonları önlemek; konuşma, çiğneme, yutma gibi fonksiyonel işlevlerdeki sorunlara palyatif amaçlı destek sağlamaktır. Bu lezyonlar, ana tümör olan RHK gibi radyoterapi ve kemoterapiye dirençlidir. Ancak uygulanan

\section{Referanslar:}

1. Lieder A, Guenzel T, Lebentrau S et al. Diagnostic relevance of metastatic renal cell carcinoma in the head and neck: An evaluation of 22 cases in 671 patients. Int Braz J Urol. 2017;43(2):202-208.

2. Mai KT, Landry DC, Robertson SJ, et al. A comparative study of metastatic renal cell carcinoma with correlation to subtype and primary tumor. Pathol Res Pract 2001;197: 671-5.

3. Selvi $\mathrm{F}$ et al. Three Synchronous Atypical Metastases of Clear Cell Renal Carcinoma to the Maxillary Gingiva, Scalp and The Distal Phalanx of the Fifth Digit: A Case Report J Oral Maxiilofac Surg. 2016.

4. Tosco L, Palazzetti A, Crivellaro S et al. Batson's paravertebral venous plexus and single vertebral metastases from renal cell carcinoma. Urologia. 2010;77:42-6.

5. Hirshberg A, Leibovich P, Buchner A. Metastases to the oral mucosa: analysis of 157 cases. J Oral Pathol Med 1993;22:385-90.

12. Kyan A, Kato SN: Renal cell carcinoma to the base of tongue: a case report. Hinyokika Kiyo 2004, 50(11):791793. lokal radyoterapi, semptomlarda kısa süreli rahatlama sağlayabilir(13). Metastatik RHK olgularında kullanılan hedefe yönelik immunoterapötik ajanlar, bu olgularda kullanılsa da sağ kalıma katkısı azdır.

\section{Sonuç}

RHK' un baş boyun bölgesine metastazı oldukça nadir görülmekteyken, gingiva metastazı daha da azdır. Yine de hastada bilinen RHK öyküsü varsa, baş boyun bölgesinde yeni oluşan kitle veya tümöral lezyon varlı̆̆ında, ayırıcı tanıda metastaz akla gelmelidir. Kesin tanı immunhistopatolojik olarak ortaya konulmaktadır. Prognozu çok kötü olduğundan, tedavi yaklaşımları sağ kalım avantajı sağlamaktan ziyade, palyatif amaçlı olmaktadır.

\section{Conflict of interest: None Çıkar Çatışması: Yok}

6. Yoshitomi I, Kawasaki G, Mizuno A et al. Lingual metastasis as an initial presentation of renal cell carcinoma. Med Oncol. 2011;28(4):1389-94.

7. Buchner A, Begleiter A. Metastatic renal cell carcinoma in the gingiva mimicking a hyperplastic lesion,Case report. J Periodontol.1980; 51(7):413-5.

8. Rusha AEA, Kamal EHM. Metastatic clear cell renal cell carcinoma presenting with a gingival metastasis. Clinics and Practice 2016;6:847.

9. Altınel D, Etit D, Tan A et al. Metastatic Renal Cell Carcinoma Initially Presented as a Tongue Mass. Turkish Journal of Pathology2010;26:261-3.

10. Majewska H, Skálová A, Radecka K et al. Renal clear cell carcinoma metastasis to salivary glands - a series of 9 cases: clinico-pathological study. Pol J Pathol. 2016 Mar;67(1):39-45

11. Bolat D, Bolat E, Duzcan SE et al. Gingival Metastasis of Renal Cell Carcinoma: Case Report. Turkiye Klinikleri J Urology 2012;3:52-5

13. Will TA, Agarwal N, Petruzzelli GJ. Oral cavity metastasis of renal cell carcinoma: A case report. J Med Case Rep 2008,2:313. 